\title{
Low-pressure solvent extraction of oil from macauba (Acrocomia aculeata) pulp: characterization of oil and defatted meal
}

\author{
Extração por solvente a baixa pressão do óleo da polpa de macaúba \\ (Acrocomia aculeata): caracterização de óleo e farelo desengordurado
}

\author{
Caroline Portilho Trentini ${ }^{\mathrm{I}}$ Dalany Menezes Oliveira ${ }^{\mathrm{II}}$ \\ Cristina Maria Zanette ${ }^{I I I}$ Camila da Silva ${ }^{I V}$
}

\section{ABSTRACT}

This study aimed to extract the oil from macauba pulp using a low-pressure solvent extraction, as well as characterisation of the extracts and defatted meal obtained using different solvents (n-hexane, ethyl acetate and isopropanol). Results reported higher yields in oil, $27.43 \%$, using isopropanol $(P<0.05)$, wherein the highest levels of $\beta$-carotene in the extract, $348.30 \mathrm{mg}^{100 \mathrm{~g}^{-1} \text {, were }}$ obtained with this solvent. In the composition of the extracts, monounsaturated fatty acids were predominantly found, and it was reported that the type of solvent had no significant influence $(P>0.05)$ on the composition; however, in the quantification of free glycerol compounds, isopropanol showed higher levels, $104.15 \mathrm{mg}$ $100 \mathrm{~g}^{-1}$, of these compounds $(P<0.05)$. Meals had higher ash, protein and fibre content when compared to pulp. Thus, oil removal can be stated to promote water retention capacity; however, it has no influence on the other technological characteristics evaluated.

Key words: Acrocomia aculeata, vegetable oil, defatted meal.

RESUMO

O presente trabalho objetivou a extração do óleo da polpa de macaúba utilizando extração por solvente a baixa pressão, bem como a caracterização dos extratos e farelos obtidos, utilizando diferentes solventes (n-hexano, acetato de etila e isopropanol). Os resultados reportam maiores rendimentos em óleo, 27,43\%, na utilização do isopropanol $(P<0,05)$, sendo

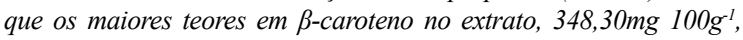
foram obtidos com este solvente. Na composição dos extratos, predominam os ácidos graxos monoinsaturados e relata-se que o tipo de solvente não apresentou influência significativa $(P>0,05)$ na composição, no entanto, na quantificação dos compostos livres de glicerol, o isopropanol apresentou os maiores teores, $104,15 \mathrm{mg}$ $100 \mathrm{~g}^{-1}$, desses compostos $(P<0,05)$. Os farelos apresentaram maiores teores de cinzas, proteina e fibras, quando comparados à polpa. A remoção do óleo favorece a capacidade de retenção de água, no entanto, não tem influência nas demais características tecnológicas avaliadas.

Palavras-chave: Acrocomia aculeata, óleo vegetal, farelo desengordurado.

\section{INTRODUCTION}

Macauba (Acrocomia aculeata) has high oil content ( $\sim 30 \%$ ) (CICONINI et al., 2013$)$; the pulp is around $45 \%$ of the fruit composition (RAMOS et al., 2008) and provides oil that is orange-yellow in colour, rich in bioactive compounds and fatty acid composition, and contains high levels of oleic and palmitic acids (HIANE et al., 2005; AMARAL et al., 2011; COIMBRA \& JORGE, 2011). Among the bioactive compounds, there is $\beta$-carotene, a powerful antioxidant, which is a precursor of vitamin $\mathrm{A}$ in human and animal metabolism, and flavonoids, which belong to the group of phenolic compounds, and are especially known for their antioxidant activity and several biological effects (HUBER \& RODRIGUEZ-AMAYA, 2008).

Among the methods available for the extraction of vegetable oils, extraction by pressing and solvent extraction are the conventional techniques.

\footnotetext{
'Programa de Pós-graduação em Bioenergia, Universidade Estadual de Maringá (UEM), Maringá, PR, Brasil.

IIPrograma de Pós-graduação em Ciência de Alimentos, Universidade Estadual de Maringá (UEM), Maringá, PR, Brasil.

IIIDepartamento de Engenharia de Alimentos, Universidade do Centro Oeste (UNICENTRO), Guarapuava, PR, Brasil.

IV Departamento de Tecnologia, Universidade Estadual de Maringá (UEM), 87506-370, Umuarama, PR, Brasil. E-mail: camiladasilva.eq@gmail.com.

Corresponding author. 
Recently, studies have been developed as alternatives to these traditional methods using solvents that are acceptable in the food industry such as ethyl acetate (ALMEIDA et al., 2012; TIAN et al., 2013), and isopropanol (SETH et al., 2007; DUTTA et al., 2014; RAMLUCKAN et al., 2014), among others. Among the techniques applied using such solvents, the researches of JESUS et al. (2013) and OLIVEIRA et al. (2013) reports pressurized liquid extraction and low-pressure solvent extraction for the extraction of palm and passion fruit seed oil, respectively, with good yields of oil. Regarding the oil obtained from Macauba pulp, in the literature there are reports of the use of organic solvent extraction in a Soxhlet (HIANE et al., 2005; RAMOS et al., 2008; COIMBRA \& JORGE, 2011) and pressing (SILVA \& ANDRADE, 2013).

The defatted Macauba meal, after oil extraction and drying, can be utilised as dietary fibre or for animal feed. Oil removal can enhance the technical characteristics of the meal due to the increased protein and dietary fibre content, and determination of these characteristics is essential for establishing the potential for incorporation of this byproduct. Dietary fibre can also impart some functional properties to foods, e.g., increase water holding capacity, oil holding capacity, emulsification and/or gel formation. Indeed, the dietary fibre incorporated into food products (bakery products, dairy, jams, meats, soups) can modify textural properties, avoid synaeresis (the separation of liquid from a gel caused by contraction), stabilise high fat food and emulsions, and improve shelf-life (ELLEUCH et al., 2011).

According to the described context, this study aimed to evaluate solvents for the extraction of Macauba pulp oil, with experiments conducted at low pressure, and the characterization of the extracts and defatted meals obtained.

\section{MATERIALS AND METHODS}

The fruits of Aculeata acrocomia were collected, about $20 \mathrm{~kg}$, in Cariri - Ceará. Fruits were sanitized; separation of the parts was carried out and pulp, with $29.51 \pm 0.48^{\circ}$ Brix, was dried at $60^{\circ} \mathrm{C}$ for $8 \mathrm{~h}$, with humidity determined to be $3.6 \pm 0.1 \%$. Pulp was ground using an electric mill (Marconi) and classified using sieves series Tyler (Bertel, ASTM) to produce particles with an average diameter of $0.5 \mathrm{~mm}$. For the extraction, the following solvents were used: ethyl acetate (99.5\%, F Maia), $n$-hexane (98.5\%, Synth) and isopropanol (99.8\%, JT Baker). Analytical standards methyl heptadecanoate, 5 $\alpha$-cholestane and $\beta$-carotene, and derivatising BF3-methanol and
N,O-bis (trimethylsilyl) trifluoro-acetamide-BSTFA with trimethylchlorosilane-TMCS were obtained from Sigma-Aldrich with purity $>99 \%$.

Oil extraction was performed at $40^{\circ} \mathrm{C}$, 40rpm and 4 hours on orbital shaker (Marconi, MA $839 / \mathrm{A}$ ), where $5 \mathrm{~g}$ of pulp was placed in flasks with a glass cover $(250 \mathrm{ml})$ together with solvents in the ratio 1:8 (weight of pulp: volume of solvent). The amount of solvent was selected after preliminary tests indicate that the increase in the ratio of $1: 2$ to $1: 8$ increases the extraction of oil; however, the use of higher ratios than 1:8 gave no significant differences in yield. After the extraction period, the samples were filtered and excess solvent in the filtrate was evaporated via the evaporator route (Marconi, MA120), and the remainder kept in an oven (Marconi, MA035) to constant weight. The extracts were stored under refrigeration (Consul) until the time of analysis. The yield was calculated as the ratio of mass of oil extracted and the mass of the pulp used.

The concentration of $\beta$-carotene in the extracts was determined at $450 \mathrm{~nm}$ using a UV spectrophotometer (Femto 700 plus). Samples were prepared in $n$-hexane and $\beta$-carotene content was determined using calibration curve for concentrations of $1.0-100.0 \mathrm{mg} \mathrm{L}^{-1}$, which showed a regression coefficient of 0.998 . The analysis of total flavonoids was performed according to the procedure reported by FRANCIS (1982). To determine the composition of fatty acids and free glycerol compounds, gas chromatographs coupled to a mass spectrophotometer were used (Thermo-Finnigan), with a capillary column Agilent HP-5MS (30m x $0.250 \mathrm{~mm} \times 0.25 \mu \mathrm{m})$, injection 0.4 of $\mu \mathrm{L}$ in split mode $1: 10$ and helium as a carrier gas, at a flow of $1 \mathrm{~mL} \mathrm{~min}^{-1}$. Identification of components present in the samples was performed by Xcalibur $^{\circledR}$ software (Thermo Electron).

For determination of the fatty acids, the samples were derivatised following the method of AOCS Ce 2-66 (WALKER, 1990) and analysed using the following chromatographic conditions: initial temperature of the column $120^{\circ} \mathrm{C}$, maintained at this temperature for 5 minutes, increasing to $180^{\circ} \mathrm{C}$ at a rate of $15^{\circ} \mathrm{C} \mathrm{min}^{-1}$ and for $240^{\circ} \mathrm{C}$ at a rate of $5^{\circ} \mathrm{C}$ $\mathrm{min}^{-1}$, staying for five minutes. The free glycerol compounds were converted to silylated compounds, as outlined by FREITAS et al. (2008), with modifications. Approximately $30 \mathrm{mg}$ of oil was derivatised with $20 \mu \mathrm{L}$ of BSTFA/TMCS with the subsequent addition of analytical standards $5 \alpha$-cholestane and methyl heptadecanoate to quantify the phytosterols and free fatty acids, respectively. The solution was stirred and remained 30 minutes at $60^{\circ} \mathrm{C}$. The analyses were performed under the following conditions: initial 
temperature of the column $100^{\circ} \mathrm{C}$, maintained at this temperature for 6 minutes, increasing to $230^{\circ} \mathrm{C}$ at a rate of $5^{\circ} \mathrm{C} \mathrm{min}{ }^{-1}$ and $280^{\circ} \mathrm{C}$ at $15^{\circ} \mathrm{C} \mathrm{min}{ }^{-1}$, where it was held for 15 minutes.

The defatted Macauba meal was dried in an oven with forced air circulation at $60^{\circ} \mathrm{C}$ (MA 035, Marconi). Dried material was ground in a knife mill type Willye (SL-031, Solab) and passed through a set of sieves with particle separation as a result of being subjected to vibration for $10 \mathrm{~min}$. Defatted meal with particle size of $100 \mu \mathrm{m}$ was used in the analysis. Hydration properties of the defatted meal were determined as per the procedure reported by ROBERTSON et al. (2000) and SEIBEL \& BELIA (2009). Water retention capacity (WRC) was defined as the quantity of water that remains bound to the hydrated fibre following the application of an external force. Swelling capacity (SC) is a measure of the ratio of volume occupied when the sample is immersed in an excess of water and after equilibration to the actual weight (RAGHAVENDRA et al., 2006). Oil absorption capacity (OAC) was determined according to RAGHAVENDRA et al. (2006) and was calculated as the ratio of quantity of fat compared to the initial dry weight of residue. Emulsification activity (EA) was investigated using the method described by DENCH et al. (1981) and was expressed as a percentage. The physicochemical analyses were carried out according to the methodologies of AOAC (1990) and used the colorimeter (Minolta CR-400) to determine colour values, $\mathrm{L}^{*}, \mathrm{a}^{*}$ and $\mathrm{b}^{*}$.

All experiments and analyzes were performed in triplicate and data were subjected to one-way ANOVA and Tukey tests $(\mathrm{P}>0.05)$, using Excel $^{\circledR} 2010$ software, to evaluate differences in the results when using different solvents.

\section{RESULTS AND DISCUSSION}

The results in oil yield using different solvents, $\beta$-carotene and flavonoids content in the extracts obtained are shown in table 1. The results demonstrate higher yield for the use of isopropanol and reports that yield using ethyl acetate and $n$-hexane showed no significant difference $(\mathrm{P}>0.05)$. Oil extraction may be attributed to the polarity of the solvents (TAKEUCHI et al., 2009; RAMLUCKAN et al., 2014), the ethyl acetate has a higher polarity, followed by isopropanol, and $n$-hexane had apolar properties. The use of polar solvents allows high yields to be obtained due to the ability of these solvents to break up the forces that bind lipids in the vegetable matrix (AQUINO et al., 2011). The apolar solvents selectively extract surface lipids (RAMLUCKAN et al., 2014); since the isopropanol, as an alcohol, may have bipolar characteristics, with superior performance compared to other solvents, this is suitable for extraction of active compounds (ALMEIDA et al., 2012) and lipid fraction (RODRIGUEZ-SOLANA et al., 2014). Literature reports that the isopropanol was more efficient at removing soybean oil flakes (SETH et al., 2007) and seeds of Crotalaria juncea (DUTTA et al., 2014) compared to $n$-hexane. It can be seen in table 1 that oil yields between 23 and $27.43 \%$ were obtained, and the literature reports contents of $18.7 \%$ to $29 \%$ oil in the pulp of Acrocomia aculeata (COIMBRA \& JORGE, 2012; CICONINI et al., 2013).

It was observed that ethyl acetate gave an extract with a higher concentration of flavonoids, followed by isopropanol and $n$-hexane, which is an expected result since flavonoids are polar molecules (HUBER \& RODRIGUEZ-AMAYA, 2008). Regarding $\beta$-carotene content, isopropanol and $n$-hexane showed greater efficiency in the extraction of this compound, but there was no significant difference between the solvents. Carotenoids present in general molecules with nonpolar characteristics are easily extracted by $n$-hexane (JAIME et al., 2010; AQUINO et al., 2011; MUSTAPA et al., 2011); however, alcohols may have bipolar characteristics, dissolving easily nonpolar organic substances

Table 1 - Results from oil yield, $\beta$-carotene and flavonoids contents in pulp and extracts obtained with different solvents. Means followed by same letters (in each row) did not differ statistically $(\mathrm{P}>0.05)$.

\begin{tabular}{|c|c|c|c|c|}
\hline & Pulp & Ethyl acetate & $n$-hexane & Isopropanol \\
\hline Yield (\%) & $25.72 \pm 0.02^{1}$ & $22.97 \pm 0.33^{\mathrm{a}}$ & $23.39 \pm 0.15^{\mathrm{a}}$ & $27.43 \pm 0.33^{b}$ \\
\hline$\beta$-carotene $\left(\mathrm{mg} 100 \mathrm{~g}^{-1}\right)$ & $124.16 \pm 0.46$ & $308.38 \pm 0.60^{\mathrm{a}}$ & $334.05 \pm 0.47^{\mathrm{b}}$ & $348.30 \pm 0.31^{\mathrm{c}}$ \\
\hline Flavonoids (mg $100 \mathrm{~g}^{-1}$ ) & $25.34 \pm 0.28$ & $16.97 \pm 0.11^{\mathrm{a}}$ & $13.78 \pm 0.09^{\mathrm{b}}$ & $14.78 \pm 0.05^{\mathrm{c}}$ \\
\hline
\end{tabular}

${ }^{1}$ Obtained by Soxhlet with petroleum ether as solvent at reflux for 8 hours 
(TAKEUCHI et al., 2009). As a result, the $\beta$-carotene can be extracted by appropriate solvents such as isopropanol. Furthermore, SACHINDRA et al. (2006) evaluated the solubility of carotenoids in different solvents and reported a high solubility of this compound in isopropanol.

Table 2 shows the composition of extracts in terms of fatty acids and free glycerol compounds. Regarding fatty acid composition, it appears that, in general, the levels were not affected $(\mathrm{P}>0.05)$ by the solvent extractor. As indicated by the results presented in table 2 , the extracts showed high contents of oleic acid $(\sim 60 \%)$ and palmitic acid $(\sim 27 \%)$, and low concentrations of linoleic acid $(\sim 6 \%)$ and linolenic $(\sim 3 \%)$. Other authors report similar results for the composition of Macauba pulp oil, such as the research of HIANE et al. (2005), which reported the predominance of acids oleic $(62.2 \%)$ and palmitic (18.5\%), and the study of AMARAL et al. (2011), which showed oleic $(69.07 \%)$, palmitic $(12.18 \%)$ and linoleic $(6.77 \%)$ acids to be the main compounds in the oil composition.

To verify the results of quantification of free glycerol compounds shown in table 2, it appears that the oil extraction using isopropanol generated higher levels of these compounds $(\mathrm{P}<0.05)$. Results obtained by ELLER et al. (2010) suggested a greater extraction of free glycerol compounds using a polar solvent. Percentage of free fatty acids (FFAs) in the extracts ranged from 1.13 to $1.34 \%$. COIMBRA \& JORGE (2011) and HIANE et al. (2005) reported levels of free fatty acids in the Macauba pulp oil extracted by Soxhlet of $9.43 \%$ and $0.83 \%$, respectively. Differences in the levels reported in the literature and obtained in this study may be explained due to the different regions, climatic conditions, drying times and temperatures to which the pulp was exposed before the oil extraction, even when the extraction method is the same (CICONINI et al., 2013). Regarding phytosterols, campesterol, stigmasterol and $\beta$-sitosterol have been identified in macauba pulp oil, with total contents ranging from 76.85 to $104.15 \mathrm{mg} 100 \mathrm{~g}^{-1}$. According to our findings, there probably has been no research reporting the quantification of phytosterols in Macauba pulp oil.

Physic-chemical characterization of pulp (without oil removal) and meal obtained as coproducts of the extraction with different solvents is shown in table 3. It can be seen that the removal of oil made possible to increase the levels of ash, protein and fibre in the meal, without any statistically significant difference between the different solvents used. Comparing the colour results shown in table 3 , it is clear that there is a decrease of $b^{*}$ (ranging from yellow/+ to green/-) with the removal of oil. Similarly, bran has a sharp white colour $\left(\mathrm{L}^{*}\right)$ and the red tone $\left(\mathrm{a}^{*}\right)$ is reduced with oil extraction.

Regarding the technological characteristics, it was reported that the oil removal increased water retention capacity and did not affect the other technological characteristics; also, the type of solvent does not influence the technological characteristics of the meal under the conditions evaluated in this study, as can be seen in table 1 . The water retention capacity of Macauba defatted meal (3.98g g-1 dry matter) was higher compared to other dietary fibres such

Table 2 - Quantification of fatty acids, free fatty acids (FFA) and phytosterols in the Macauba pulp oil obtained with different solvents. Means followed by same letters (in each row) did not differ statistically $(\mathrm{P}>0.05)$.

\begin{tabular}{|c|c|c|c|c|}
\hline Solvent & & Ethyl acetate & $n$-hexane & Isopropanol \\
\hline \multirow{9}{*}{ Fatty acids ${ }^{1}$} & Caprilic & $0.27 \pm 0.03^{\mathrm{a}}$ & $0.13 \pm 0.01^{\mathrm{b}}$ & $0,09 \pm 0,01^{\mathrm{b}}$ \\
\hline & Capric & $0.04 \pm 0.01^{\mathrm{a}}$ & $0.06 \pm 0.01^{\mathrm{a}}$ & $0,03 \pm 0,01^{\mathrm{b}}$ \\
\hline & Lauric & $0.09 \pm 0.01^{\mathrm{a}}$ & $0.11 \pm 0.01^{\mathrm{a}}$ & $0,11 \pm 0,01^{\mathrm{a}}$ \\
\hline & Myristic & $0.22 \pm 0.01^{\mathrm{a}}$ & $0.18 \pm 0.02^{\mathrm{a}}$ & $0,18 \pm 0,01^{\mathrm{a}}$ \\
\hline & Palmitic & $27.77 \pm 0.29^{\mathrm{a}}$ & $27.39 \pm 0.12^{\mathrm{a}}$ & $27,24 \pm 0,42^{\mathrm{a}}$ \\
\hline & Stearic & $1.81 \pm 0.29^{\mathrm{a}}$ & $1.80 \pm 0.14^{\mathrm{a}}$ & $2,48 \pm 0,46^{\mathrm{a}}$ \\
\hline & Oleic & $61.03 \pm 0.48^{\mathrm{a}}$ & $61.15 \pm 0.15^{\mathrm{a}}$ & $60,17 \pm 0,51^{\mathrm{a}}$ \\
\hline & Linoleic & $5.79 \pm 0.03^{\mathrm{a}}$ & $6.34 \pm 0.19^{\mathrm{b}}$ & $5,72 \pm 0,07^{\mathrm{a}}$ \\
\hline & Linolenic & $2.96 \pm 0.11^{\mathrm{ab}}$ & $2.81 \pm 0.05^{\mathrm{a}}$ & $3,09 \pm 0,07^{\mathrm{b}}$ \\
\hline $\mathrm{FFA}^{1}$ & & $1,13 \pm 0,01^{\mathrm{a}}$ & $1.15 \pm 0.02^{\mathrm{a}}$ & $1.34 \pm 0.01^{\mathrm{b}}$ \\
\hline Phytosterols $^{2}$ & & $82,45 \pm 0,71^{\mathrm{a}}$ & $76.85 \pm 0.48^{\mathrm{b}}$ & $104.15 \pm 0.73^{\mathrm{c}}$ \\
\hline
\end{tabular}

${ }^{1}$ Results in g $100 \mathrm{~g}^{-1}$ of oil; ${ }^{2}$ Results in mg of PT $100 \mathrm{~g}^{-1}$ of oil. 
Table 3 - Physicochemical and technological characteristics and color of Macauba pulp and defatted meal (dry basis). Means followed by same letters (in each row) did not differ statistically $(\mathrm{P}>0.05)$.

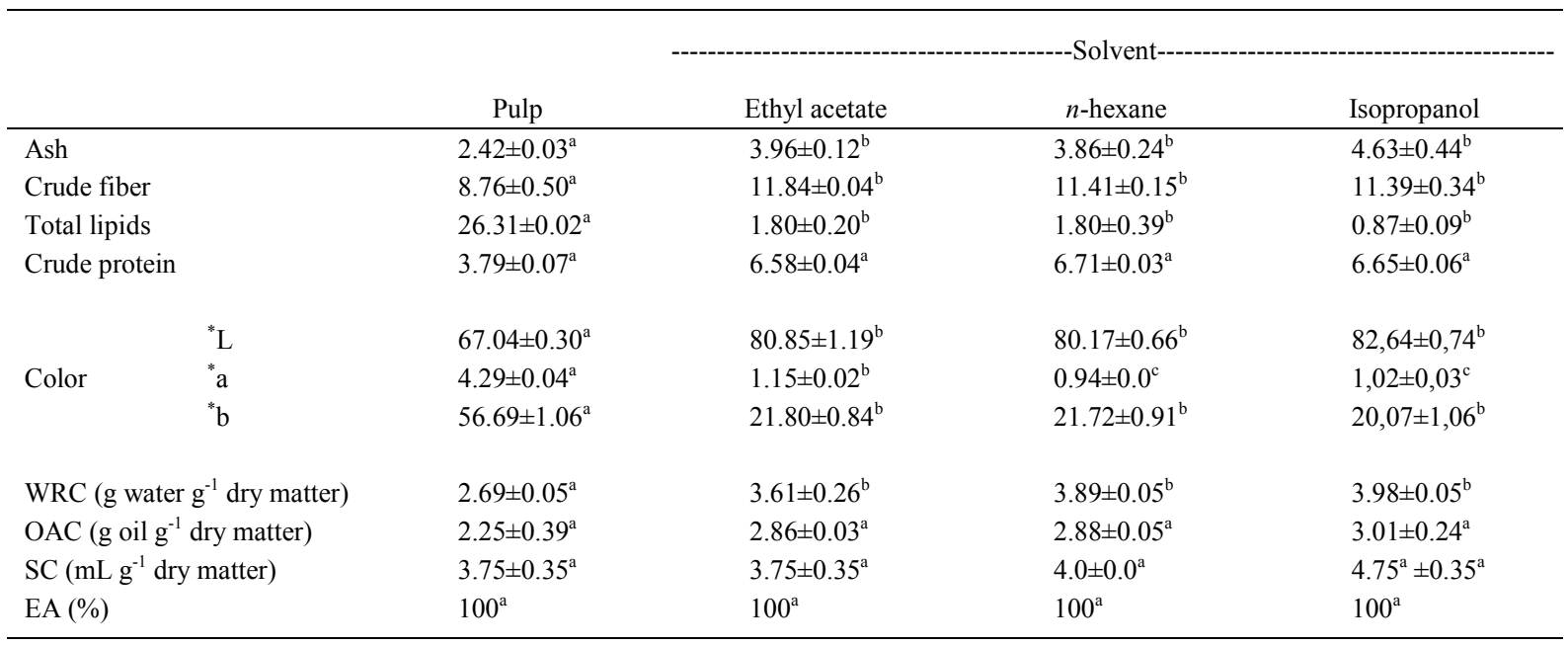

WRC: water retention capacity; OAC: oil absorption capacity; SC: swellin capacity; EA: Emulsification activity.

as apple, pea, wheat and carrot (values ranged 2.5 to $3.5 \mathrm{~g} \mathrm{~g}^{-1}$ dry matter) (THEBAUDIN et al., 1997). The oil absorption capacity $\left(3.01 \mathrm{~g} \mathrm{~g}^{-1}\right.$ dry matter $)$ and emulsification activity $(100 \%)$ were higher than those reported for defatted soy flour $2.4 \mathrm{~g} \mathrm{~g}^{-1}$ dry matter and $56.8 \%$, respectively (SIEBEL, 2009). Ability of defatted meal to absorb and retain water and oil may help to improve the binding capacity, enhance flavour retention, improve mouth feel and reduce moisture and fat losses of extended meat products (KAUR et al., 2013). Values of technological characteristics found in this research suggested some possibilities about the use of Macauba defatted meal as ingredients in food products, such as meat products, mayonnaise and bakery products.

\section{CONCLUSION}

The Macauba pulp oil obtained in this research used different solvents and proved to be rich in $\beta$-carotene, flavonoids and monounsaturated fatty acids. Isopropanol showed higher oil yield, $\beta$-carotene and free glycerol compounds. Ethyl acetate provided extracts with higher concentrations of flavonoids. Results showed that Macauba oil with good quality, before the evaluated characteristics, can be obtained by extraction technique adopted. The meals presented increased water retention capacity when compared to the pulp resulting from the change in centesimal composition and presents technological characteristics for use in food formulations.

\section{ACKNOWLEDGEMENTS}

The authors thank Conselho Nacional de Desenvolvimento Científico e Tecnológico (CNPq), Coordenação de Aperfeiçoamento de Pessoal de Nível Superior (CAPES) and Universidade Estadual de Maringá (UEM).

\section{REFERENCES}

AOAC (ASSOCIATION OF OFFICIAL ANALYTICAL CHEMIST). Official methods of analysis, $15^{\text {th }}$ edition, Gaithersburg, 1990. 771p.

ALMEIDA, P.P. et al. Extraction of Mentha spicata L. volatile compounds: evaluation of process parameters and extract composition. Food Bioprocess Technology, v.5, p.548-559, 2012. Available from: $<$ http://link.springer.com/article/10.1007\%2Fs11947-010-0356-y>. Accessed: Oct. 02, 2014. doi: 10.1007/s11947-010-0356-y.

AMARAL, F.P. et al. Extraction and qualitative characterization of pulp and almonds oils of macauba fruits [Acrocomia aculeata (Jacq) Lo dd. ex Mart] collected in the region of Botucatu, SP. Revista Energia na Agricultura, v.26, p.12-20, 2011. Available from: $<$ http://dx.doi.org/10.17224/EnergAgric.2011v26n1p12-20>. Accessed: Oct. 25, 2014.

AQUINO, L.P. et al. Extraction of oil from pequi fruit (Caryocar Brasilence, Camb) using several solvents and their mixtures. Grasas y Aceites, v.62, p.245-252, 2011. Available from: $<$ http://grasasyaceites. revistas.csic.es/index.php/grasasyaceites/article/viewArticle/1322>. Accessed: Feb. 10, 2014. doi: 10.3989/gya.091010.

CICONINI, G. et al. Biometry and oil contents of Acrocomia aculeata fruits from the Cerrados and Pantanal biomes in Mato Grosso do Sul, Brazil. Industrial Crops Products, v.45, p.208-214, 2013. Available from: <http://dx.doi.org/10.1016/j. indcrop.2012.12.008>. Accessed: Feb. 02, 2015. doi: 10.1016/j. indcrop.2012.12.008.

Ciência Rural, v.46, n.4, abr, 2016. 
COIMBRA, M.C.; JORGE, N. Characterization of the pulp and kernel oils from Syagrus leracea, Syagrus romanzoffiana, and Acrocomia aculeata. Journal of Food Science, v.76, p.1156-1161, 2011. Available from: <http://dx.doi.org/10.111 1/j.1750-3841.2011.02358.x>. Accessed: Feb. 10, 2015. doi: 10.1111/j.1750-3841.2011.02358.x.

COIMBRA, M.C.; JORGE, N. Fatty acids and bioactive compounds of the pulps and kernels of Brazilian palm species, guariroba (Syagrus oleraces), jerivá (Syagrus romanzoffiana) and macaúba (Acrocomia aculeata). Journal of the Science of Food and Agriculture, v.92, p.679-684, 2012. Available from: $<$ http://dx.doi.org/10.1002/jsfa.4630>. Accessed: Jan. 15, 2015. doi: $10.1002 /$ jsfa.4630.

DENCH, J.E. et al. Selected functional properties of sesame (Sesamum indicum L.) flour and two protein isolates. Journal of the Science of Food and Agriculture, v.32, p.557-564, 1981. Available from: <http://dx.doi.org/10.1002/jsfa.2740320606>. Accessed: Nov. 05, 2014. doi: 10.1002/jsfa.2740320606.

DUTTA, R. et al. Extraction of oil from Crotalaria Juncea seeds in a modified Soxhlet apparatus: physical and chemical characterization of a prospective bio-fuel. Fuel, v.116, p.794-802, 2014. Available from: <http://dx.doi.org/10.1016/j.fuel.2013.08.056>. Accessed: Nov. 10, 2014. doi: 10.1016/j.fuel.2013.08.056.

ELLER, F.J. et al. Extraction and analysis of tomato seed oil. Journal of the American Oil Chemists' Society, v.87, p. 755762, 2010. Available from: $<$ http://http://link.springer.com/article/ 10.1007\%2Fs11746-010-1563-4>. Accessed: May 13, 2015. doi: $10.1007 / \mathrm{s} 11746-010-1563-4$.

ELLEUCH, M. et al. Dietary fibre and fibre-rich by-products of food processing: characterization, technological functionality and commercial applications: a review. Food Chemistry, v.124, p.411-421, 2011. Available from: <http://dx.doi.org/10.1016/j. foodchem.2010.06.077>. Accessed: Feb. 02, 2015. doi: 10.1016/j. foodchem.2010.06.077

FRANCIS, F.J. Analysis of anthocyanins. In: MARKAKIS, P. (Ed.) Anthocyanins as food colors. New York: Academic, 1982. p.181-207.

FREITAS, L.S. et al. Extraction of grape seed oil using compressed carbon dioxide and propane: extraction yields and characterization of free glycerol compounds. Journal of Agriculture and Food Chemistry, v.56, p.2558-2564, 2008. Available from: <http:// pubs.acs.org/doi/abs/10.1021/jf0732096>. Accessed: Jan. 25, 2015. doi: $10.1021 /$ jf0732096.

HIANE, P.A. et al. Bocaiúva, Acrocomia aculeate (Jacq.) Lodd., pulp and kernel oils: characterization and fatty acid composition. Brazilian Journal of Food Technology, v.8, p.256-259, 2005. Available from: <http://bjft.ital.sp.gov.br/artigos/html/busca/PDF/ v8n3212a.pdf>. Acessed: Feb. 02, 2015.

HUBER, L.S.; RODRIGUEZ-AMAYA, D.B. Flavonóis e flavonas: fontes brasileiras e fatores que influenciam a composição em alimentos. Alimentos e Nutrição, v.19, p.97-108, 2008. Available from: $<\mathrm{http} / /$ serv-bib.fcfar.unesp.br/seer/index.php/alimentos/article/ viewArticle/205>. Accessed: Sept. 15, 2014.

JAIME, L. et al. Pressurized liquids as an alternative process to antioxidant carotenoids' extraction from Haematococcus pluvialis microalgae. LWT - Food Science and Technology, v.43, p.105-112, 2010. Available from: <http://dx.doi.org/10.1016/j. lwt.2009.06.023>. Accessed: Dec. 10, 2014. doi: 10.1016/j. lwt.2009.06.023.

JESUS, A.A. et al. Extraction of palm oil using propane, ethanol and its mixtures as compressed solvent. Journal of Supercritical Fluids, v.81, p.245-253, 2013. Available from: <http://dx.doi. org/10.1016/j.supflu.2013.06.011. Accessed: Aug. 05, 2014. doi: 10.1016/j.supflu.2013.06.011.

KAUR, M. et al. Studies on physicochemical and pasting properties of Taro (Colocasia esculenta L.) flour in comparison with a cereal, tuber and legume flour. Journal of Food Science and Technology, v. 50, p.94-100, 2013. Available from: <http://link.springer.com/ article/10.1007/s13197-010-0227-6>. Accessed: Sept. 10, 2015. doi: 10.1007/s13197-010-0227-6.

MUSTAPA, A.N. et al. Extraction of $\beta$-carotenes from palm oil mesocarp using sub-critical R134a. Food Chemistry, v.125, p.262-267, 2011. Available from: <http://dx.doi.org/10.1016/j. foodchem.2010.08.042>. Accessed: Jan. 17, 2015. doi: 10.1016/j. foodchem.2010.08.042.

OLIVEIRA, R.C. et al. The extraction of passion fruit oil with green solvents. Journal of Food Engineering, v.117, p.458463, 2013. Available from: <http://dx.doi.org/10.1016/j. jfoodeng.2012.12.004>. Accessed: Nov. 12, 2014. doi: 10.1016/j. jfoodeng.2012.12.004

RAGHAVENDRA, S.N. et al. Grinding characteristics and hydration properties of coconut residue: a source of dietary fiber. Journal of Food Engineering, v.72, p.281286, 2006. Available from: <http://dx.doi.org/10.1016/j. jfoodeng.2004.12.008>. Accessed: Apr. 30, 2015.

RAMLUCKAN, K. et al. An evaluation of the efficacy of using selected solvents for the extraction of lipids from algal biomass by the Soxhlet extraction method. Fuel, v.116, p.103-108, 2014. Available from: <http://dx.doi.org/10.1016/j.fuel.2013.07.118>. Accessed: Feb. 15, 2015. doi: 10.1016/j.fuel.2013.07.118.

RAMOS, M.L.L et al. Qualidade nutricional da polpa de bocaiúva Acrocomia aculeata (Jacq.) Lodd. Ciência e Tecnologia de Alimentos, v.28, p.90-94, 2008. Available from: <http://dx.doi. org/10.1590/S0101-20612008000500015>. Accessed: Jan. 28, 2015. doi: 10.1590/S0101-20612008000500015.

SACHINDRA, N.M et al. Recovery of carotenoids from shrimp waste in organic solvents. Waste Management, v.26, p.10921098, 2006. Available from: <http://dx.doi.org/10.1016/j. wasman.2005.07.002>. Accessed: May 13, 2015. doi: 10.1016/j. wasman.2005.07.002.

SEIBEL, N.F.; BÉLIA,A.D.P. Características químicas e funcionalidade tecnológica de ingredientes de soja [Glycine Max (L.) Merril]: carboidratos e proteínas. Brazilian Journal of Food Techology, v.12, p.113-122, 2009. Available from: $<$ http://bjft.ital.sp.gov.br/artigos/html/ busca/PDF/v12n2378a.pdf>. Accessed: Feb. 05, 2015

SETH, S. et al. Oil extraction rates of soya bean using isopropyl alcohol as solvent. Biosystems Engineering, v.97, p.209217, 2007. Available from: <http://dx.doi.org/10.1016/j. biosystemseng.2007.03.008>. Accessed: Feb. 10, 2015. doi: 10.1016/j.biosystemseng.2007.03.008.

SILVA, G.C.R.; ANDRADE, M.H.C. Development and simulation of a new oil extraction process from fruit of macauba

Ciência Rural, v.46, n.4, abr, 2016. 
palm tree. Journal of Food Process Engineering, v.36, p.134-145, 2013. Available from: <http://dx.doi.org/10.1111 /j.1745-4530.2011.00657.x>. Accessed: Feb. 16, 2015. doi: 10.1111/j.1745-4530.2011.00657.x

TAKEUCHI, T.M. et al. Low-pressure solvent extraction (solidliquid extraction, microwave assisted, and ultrasound assisted) from condimentary plants. In: MEIRELES, M.A.A. Extracting bioactive compounds for food products: theory and applications. London: CRC, 2009. p.137-218.

THEBAUDIN, J.Y. et al. Dietary fibres: Nutritional and technology interest. Trends in Food Science and Technology, v.8, p.41-48, 1997. Available from: <http://dx.doi.org/10.1016/S09242244(97)01007-8>. Accessed: Feb. 15, 2015.

TIAN, Y. et al. Optimization of ultrasonic-assisted extraction of pomegranate (Punica granatum L.) seed oil. Ultrasonics Sonochemistry, v.20, p.202-208, 2013. Available from: <http:// dx.doi.org/10.1016/j.ultsonch.2012.07.010>. Accessed: Jan. 15, 2015. doi: 10.1016/j.ultsonch.2012.07.010.

WALKER, R.E. Official methods and recommended practices of the American Oil Chemists' Society (Method AOCS Ce 2-66). Champaign: American Oil Chemists Society, 1990, $4^{\text {th }}$ edition. $1220 \mathrm{p}$ 